\title{
Urban Emission Patterns at a Semi-Arid Site in Lahore, Pakistan
}

\author{
Rizwan Haider, Abdullah Yasar*, Amtul Bari Tabinda \\ Sustainable Development Study Center, GC University, Lahore Pakistan
}

Received: 25 April 2016

Accepted: 18 July 2016

\begin{abstract}
The current research is an attempt to find out diurnal and monthly mean patterns of air pollutants, their interrelationships, and their dominant sources through hourly and monthly data analysis. Lahore is a semiarid region with low rainfall, hot and humid summers, and cold dry winters. Annually, the highest air quality index (AQI) (132 to 185) is observed from November to February due to inversion at low wind speeds $\left(<1.5 \mathrm{~m} / \mathrm{s}\right.$ monthly average), low temperature $\left(15^{\circ} \mathrm{C}\right.$ to $21^{\circ} \mathrm{C}$ monthly average), and low solar radiation (104 to $140 \mathrm{~W} \mathrm{~m}-2$ monthly averages). AQI remained low (74 to 85) from June to August due to relatively heavy rain, relatively high wind speed (1.59 to 1.85 monthly averages), dispersion due to high temperatures, high solar radiation, and summer vacations to schools. With an analogous diurnal trend, the AQI remains stumpy in daytime. The high $\mathrm{CO} / \mathrm{NOx}$ ratio indicates that mobile sources are dominant contributors to $\mathrm{NOx}$; and the low $\mathrm{SO}_{2} / \mathrm{NOx}$ ratio indicates that point sources are dominant contributors to $\mathrm{SO}_{2}$. $\mathrm{CO}$ has a significant positive correlation with $\mathrm{NO}, \mathrm{NO}_{2}, \mathrm{NOx}, \mathrm{CH}_{4}, \mathrm{SO}_{2}$, and $\mathrm{RH}$, and a negative correlation with $\mathrm{O}_{3}$ and temperature. This explains why four-stroke petrol engines are common sources for $\mathrm{CO}, \mathrm{NO}, \mathrm{NO}_{2}$, and NOx. $\mathrm{PM}_{2.5}$ has a significant positive correlation with $\mathrm{SO}_{2}$, which explains why diesel engines are a common source for $\mathrm{PM}_{2.5}$ and $\mathrm{SO}_{2}$. $\mathrm{O}_{3}$ has a significant negative correlation with $\mathrm{NO}, \mathrm{NO}_{2}, \mathrm{NOx}, \mathrm{CH}_{4}, \mathrm{CO}$, and $\mathrm{RH}$; and has a significant positive correlation with temperature and solar radiation.
\end{abstract}

Keywords: semi-arid, mobile sources, air pollution, meteorology, air quality index, Pakistan

\section{Introduction}

The population of Lahore is 9 million, making it Pakistan's second largest city [1]. There are 2.7 million vehicles along with 1,986 different industrial units in Lahore [1]. The ambient air pollution in the city predominantly originates from vehicular and industrial emissions [2] .

*e-mail: yasar.abdullah@gmail.com
The semi-arid climate of Lahore naturally favors the accumulation of pollutants. Solid aerosols are present in the samples of PM [3].

New housing schemes have not been found to fulfill the needs of sustainable development and transport sustainability. The city district government has failed to achieve its target of ambient air quality improvements under the 2001 devolution plan due to the absence of transport policy, alteration in land use policy, and deprived management and monitoring of air quality [4]. Furthermore, the city has been expanding due to migration from small cities of Punjab. Migration has been observed 
from Karachi and Peshawar as well, due to security reasons.

Diesel-fueled generators have been used extensively in industrial sectors (point sources) as well as in other sectors due to widespread power shortages in the country, which adds a lot to urban ambient air pollution [5]. The use of diesel fuel by mobile sources contributes a lot to particulate matter air pollution [6]. The sulfur contents are very high in diesel (0.5-1\%) and furnace oil (1-3.5\%) being used in Pakistan, whose fallout comes with higher sulfur dioxide pollution [7].

The environmental damage is associated with health issues. Currently, mobile sources have been found to promote high levels of tropospheric ozone and health concerns in urban areas [8]. The Organosulfatese have been identified and quantified in fine particulate matter $\left(\mathrm{PM}_{2.5}\right)$ collected in Lahore, Pakistan, in 2007-08 [9]. Enhanced diastolic blood pressure has been found to be associated with long-term exposure to $\mathrm{NO}_{2}$ and $\mathrm{PM}_{25}$ in those children who used to live at the same place since birth [10]. The $\mathrm{PM}_{25}$ levels have been exceeding the NEQS in four provincial as well as federal capitals of Pakistan [11]. In the fall season during October and November; burning of crop residues in eastern Pakistan and northwestern India increase the concentrations of $\mathrm{PM}_{25}$ in the atmosphere $[12,13]$. Secondary inorganic PM in the form of sulfates and nitrates is formed by the oxidation of $\mathrm{SO}_{2}$ and $\mathrm{NOx}$. However, the organic carbon fraction is formed due to oxidation of VOCs $[14,16]$. This process is enhanced by ammonia [17]. The black carbon aerosols are present in $90 \%$ of $\mathrm{PM}_{2.5}$ in winter and contribute about $5-15 \%$ to overall $\mathrm{PM}_{2.5}$ in the ambient air $[18,19]$. Black carbon has been found to be at much higher levels during foggy season. Black carbon has also been found to be trapped in aerosols during the foggy season, resulting in a lessening of solar radiation [20].

Other big cities in Punjab also have high pollution levels. Concentrations of $\mathrm{CO}, \mathrm{NO}_{2}$, and $\mathrm{SO}_{2}$ have been found above NEQS levels in Faisalabad [21]. The traffic pollution has been found to be the most contributing factor to outdoor air pollution in most urban areas [22].

Brick kilns on the outskirts of Lahore are also a great point source of air pollution. A study of brick kilns in the Wahga and Batapur areas of Lahore revealed that the conventional Bull's Trench Brick Kiln are being used in Lahore, which comprises no control measures to manage the air pollution. Modern brick manufacturing technologies such as vertical shaft brick kiln must be introduced to control the air pollution [23].

It is impossible to monitor the spatial and temporal variations in the atmosphere on the basis of a single monitoring site [24]. In a recent study on some metals in the vehicular exhaust emissions of rickshaws, it has been discovered that a significant boost has been found in Al, P, and $\mathrm{Zn}$ in the PM samples of four-stroke Rickshaws [25]. In another study in Beijing, perfluorinated compounds (PFCs) are found in ambient $\mathrm{PM}_{2.5}, \mathrm{PM}_{10}$, and TSP [26]. The environmental damage costs the country an annual loss of about Rs. 365 billion, of which the urban air pollution loss was approximately Rs. 65 billion in 2006 [27].

\section{Materials and Methods}

Hourly air quality monitoring data for 2007-11 and 2014-15 were collected from the Provincial Environmental Protection Agency. The air quality monitoring stations remained almost out of work during 2012 and 2013 due to lack of budget to run them. Fix and mobile air quality monitoring stations had been used to monitor the six major pollutants along with meteorological parameters. The air quality monitoring stations contain an anemometer (KoshinDenkiKogyo Co., Ltd. Model KVS 501) combined wind vane, a solar radiation meter (Koshin Denki Kogyo Co., Ltd. Model SR-010), a thermohygrometer (Koshin Denki Kogyo Co., Ltd. ModelHT-010), and a data logging system (Horiba, Ltd. Model Special).

The six major air pollutants like ozone $\left(\mathrm{O}_{3}\right)$, carbon monoxide $(\mathrm{CO})$, sulfur dioxide $\left(\mathrm{SO}_{2}\right)$, oxides of nitrogen (NOx, i.e., $\mathrm{NO}$ and $\left.\mathrm{NO}_{2}\right)$, fine particulate matter $\left(\mathrm{PM}_{25}\right)$, and hydrocarbons (total hydrocarbons, non-methane hydrocarbons, and methane) were determined through analyzers described in Table 1.

The air quality index (AQI) was calculated according to "Eq.1" [28].

Table 1. Detail of instruments of air quality monitoring station.

\begin{tabular}{|c|c|c|c|c|}
\hline Pollutant & Analyzer & Range & Method & Detection Limit \\
\hline $\mathrm{CO}$ & Horiba Ltd; Model APMA-370 & $0 \sim 50 \mathrm{ppm}$ & $\begin{array}{c}\text { non-dispersive infrared ray method } \\
\text { (ISO4224) }\end{array}$ & $0.1 \mathrm{ppm}$ \\
\hline $\begin{array}{c}\mathrm{NO} / \mathrm{NO}_{2} \\
\text { NOx }\end{array}$ & Horiba Ltd; Model APNA-370 & $0 \sim 1 \mathrm{ppm}$ & $\begin{array}{c}\text { Chemiluminescence (ISO7996) } \\
\text { method }\end{array}$ & $0.5 \mathrm{ppb}$ \\
\hline $\begin{array}{c}\text { Sulfur dioxide } \\
\text { Horiba Ltd; Model APSA-370 }\end{array}$ & $0 \sim 0.5 \mathrm{ppm}$ & $\begin{array}{c}\text { U.V. fluorescence method } \\
\text { (ISO10498) }\end{array}$ & $1 \mathrm{ppb}$ \\
\hline Hydrocarbon & Horiba Ltd; Model APOA-370 & $0 \sim 1 \mathrm{ppm}$ & UV photometry method & $0.5 \mathrm{ppb}$ \\
\hline $\mathrm{PM}_{2.5}$ & Horiba Ltd; Model APDA-370 & $0 \sim 5 \mathrm{mg} \mathrm{m}{ }^{-3}$ & $\beta$-ray absorption method (ISO6349) & $0.1 \mathrm{ppmC}$ \\
\hline
\end{tabular}




$$
\begin{aligned}
\mathrm{AQI} & =\left[\left(\mathrm{NO}_{2} / 80\right)+\left(\mathrm{SO}_{2} / 120\right)+\left(\mathrm{O}_{3} / 130\right)\right. \\
& \left.+(\mathrm{CO} / 5)+\left(\mathrm{PM}_{2.5} / 35\right)\right] / 5 \times 100
\end{aligned}
$$

\section{Lahore and its Meteorology}

Lahore is located at $31^{\circ} 32^{\prime} \mathrm{N} 74^{\circ} 22^{\prime} \mathrm{E}$ at $217 \mathrm{~m}$ above sea level. The municipal area of Lahore is $332 \mathrm{~km}^{2}$. Due to rapid urbanization, the area has been extended to 1,000 $\mathrm{km}^{2}$. Two fixed air quality monitoring stations have been installed in Lahore to monitor air quality. One of the stations is installed on the second floor of the city hall building situated in the northern main commercial area of Lahore with a number of busy roads, markets, and dense population. The second station was installed in Quaid-iAzam Township area, a southern residential area near Kotlakhpat industrial estate.

The city hall air quality monitoring station was selected for data analysis. The fixed air quality monitoring station installed at city hall on Lower Mall road in Lahore represents the ambient air quality of the main city of Lahore. The monitoring station was located about $8 \mathrm{~m}$ from the ground. Most of the main roads of Lahore are within a $1-3 \mathrm{~km}$ sphere of the station. The location of the two fixed Air Quality Monitoring Stations can be seen in Fig. 1.

The climate of Lahore can be distributed into five seasons: foggy winter (15 Nov-15 Feb) with low rainfall, low wind speed, and high inversion; spring (16 Feb-5 April) with low rainfall and moderate temperature (T); summer (15 April-June) with high temperature, high rainfall, low relative humidity $(\mathrm{RH})$, and high dispersion effects; rainy monsoon (July-16 September) with high temperature, high relative humidity, and low pollution due to dispersion and washing effect; and dry autumn (16 September-14 November) with low wind speed and low RH [29].

June is the hottest month, with an average temperature of $33.9^{\circ} \mathrm{C}$. The average temperature of January is $12.8^{\circ} \mathrm{C}$, which makes it the coolest month of the year. The average annual temperature of Lahore is $24.3^{\circ} \mathrm{C}$, which is fairly hot as annual average. Average monthly temperature range is $21.1^{\circ} \mathrm{C}$. The average daily temperature variation is $15.5^{\circ} \mathrm{C}$ [29].

Minimum average sunshine has been observed in January with 6.9 hours day ${ }^{-1}$. Overall annual average sunshine is 8.4 hours day $^{-1}$ [29].

Wind speed remains low almost throughout the year except some windy days in summer. Around $60 \%$ of the year remains calm and $33 \%$ of days see an average speed of 1-3 knots. Only $6 \%$ of the year experiences speeds of 4-6 knots. Wind direction remains mostly northwest during monsoon and summer and southeast during winter [29].

Relative Humidity (RH) remains low throughout the year except during monsoon season. The monthly average of relative humidity exceeds $60 \%$ during July, August, and September. Average relative humidity remains around $77 \%$ in the morning and $40 \%$ in the evening. The average monthly relative humidity ranges around $20 \%$ in May to $58 \%$ in August. Overall, the annual average relative humidity remains around $37.9 \%$.

The climate of Lahore has observed extreme weather events in the near past. The highest ever recorded temperatures of the city were $48.3^{\circ} \mathrm{C}$ on 30 May 1944 and $48^{\circ} \mathrm{C}$ on 10 June 2007 . The highest recorded rainfall was $221 \mathrm{~mm}$, observed on 13 August 2008, and $4.5 \mathrm{~mm}$ hail was observed in Lahore on 26 February 2011 [29].

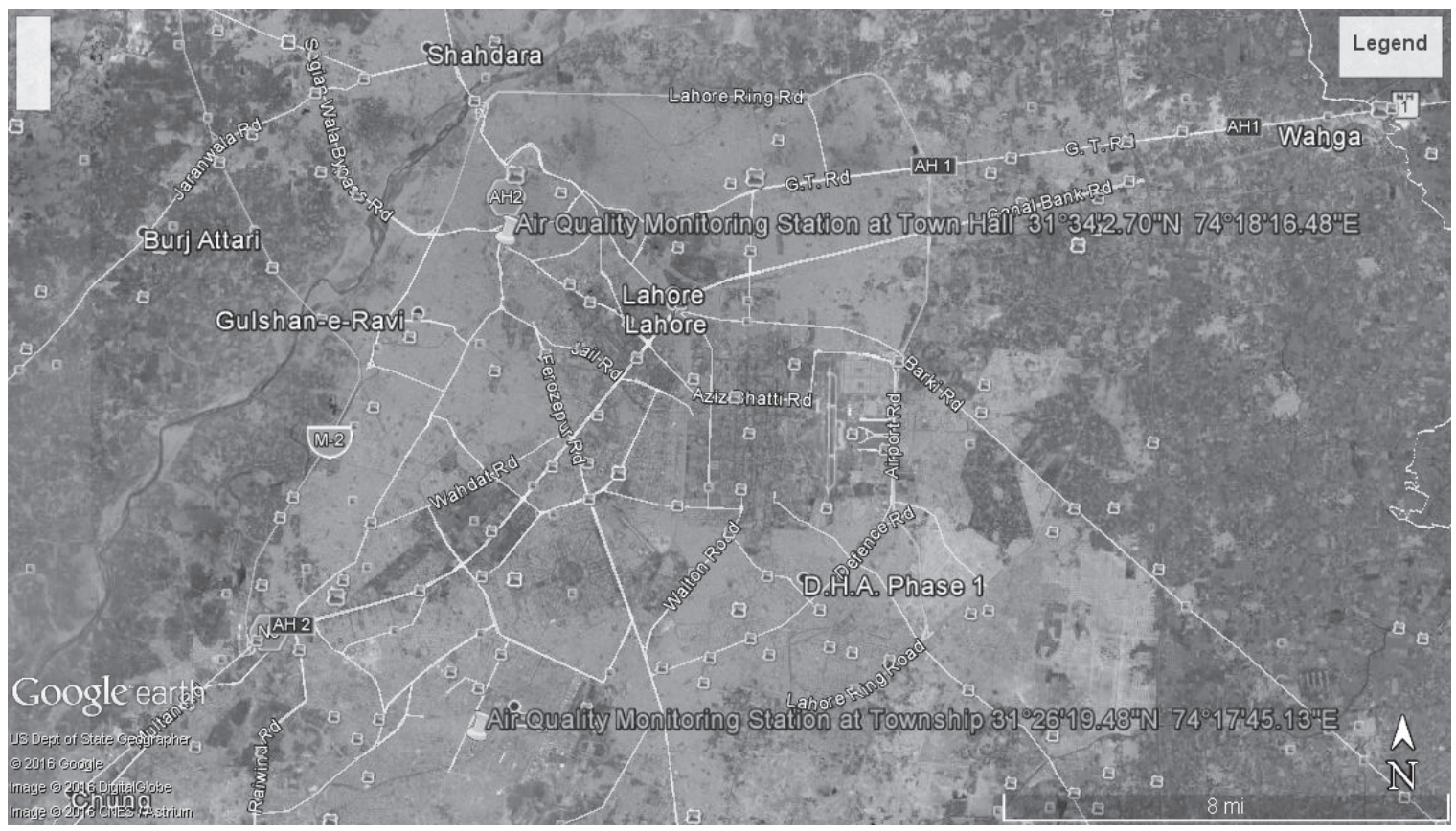

Fig. 1. Locations of automatic fixed air quality monitoring stations in Lahore (based on Google map). 
Table 2. Air quality index.

\begin{tabular}{|c|c|c|c|c|c|c|}
\hline \multirow{2}{*}{ AQI } & $0-50$ & $50-100$ & $101-150$ & $151-200$ & $201-300$ & $>300$ \\
\cline { 2 - 7 } & & & & & & \\
\hline Air Quality & Clean & Moderate & $\begin{array}{c}\text { Unhealthy for } \\
\text { sensitive }\end{array}$ & Unhealthy & Very Unhealthy & Hazardous \\
\hline
\end{tabular}

\section{Results and Discussion}

Ambient air quality data of Lahore for 2007-11 and 2014-15 has been analyzed to discern patterns and determine the sources of the six representative air pollutants. The hourly data for each pollutant collected was analyzed for average concentration, monthly mean pattern, and seasonal and diurnal variations.

\section{Air Quality Index}

The interpretation of AQI can be elaborated as clean, moderate, unhealthy, and very unhealthy. The Pakistani NEQS for $\mathrm{O}_{3}$ for 24 hours has yet not been made available. The NEQS for $\mathrm{O}_{3}$ for one hour have been revised from 180 to 130 and for $\mathrm{PM}_{2.5}$ for 24 hours have been revised from 40 to 35 since January 2013 [30]. So before January 2013, the index value would be calculated accordingly. A projected AQI is given in Table 2 [28].

AQI remains low ( $\sim 74$ to $\sim 85)$ from June to August due to heavy rain, relatively high wind speed $(\sim 1.59$ to $\sim 1.85$ monthly average), and dispersion due to high temperatures and high solar radiation. In summer, an improved air quality index also has been observed in northern China. [31].

The highest AQI $(\sim 132$ to $\sim 185)$ was observed from November to February due to inversion at low wind speed $(<1.5 \mathrm{~m} / \mathrm{s}$ monthly average), low temperature $\left(\sim 15-21^{\circ} \mathrm{C}\right.$ monthly average), and low solar radiation ( 104-140 $\mathrm{W} \mathrm{m}^{-2}$ monthly averages) due to heavy fog during December and January. Another reason for the high AQI during fall can be due to burning crop residue in southwestern India and eastern Pakistan. The wind direction during winter remains mostly southeast, which can also be a reason for contributing to pollution in Lahore from a number of polluted steel industries in the northern part of Lahore and industrial clusters in Sheikhupura and Gujranwala. The steel industries are mostly located in Badami Bagh, Misry Shah, Daroghay Wala, and around the Band Road area in northern Lahore. Fig. 1 shows a map of Lahore.

\section{Data Analysis}

For data analysis, the data of daytime (07:00-15:00) has been taken for analysis of ozone and its precursors. The data of a sunny and clear day has been taken. The mean concentration of the ozone, other pollutants, and meteorological parameters are given in Table 3.

The day is dry and hot with low mean RH (30.66), high solar radiation (about $680 \mathrm{~W} \mathrm{~m}^{-2}$ ), and high mean temperature (around $38^{\circ} \mathrm{C}$ ). Wind speed remained low (mean value $=1.72 \mathrm{~m} / \mathrm{sec}$ ) as a routine matter in semiarid regions. NO remained almost nil (mean value $=$ $1.93 \mu \mathrm{g} \mathrm{m}^{-3}$ ) during sunny hot days due to its conversion to $\mathrm{NO}_{2}$ (mean value $=26.8 \mu \mathrm{g} \mathrm{m}-3$ ) in the presence of high concentrations of $\mathrm{O}_{3}$ (mean value $\left.=122.50 \mu \mathrm{g} \mathrm{m}^{-3}\right)$. Concentrations of $\mathrm{CH}_{4}$ remained below (mean value = 2,210.61 ppb) its natural level (around 3,000 ppb) due to its consumption as a precursor of ozone. The mean value of $\mathrm{PM}_{2.5}\left(155.07 \mathrm{mg} \mathrm{m}^{-3}\right)$ remained high due to a high amount of un-burnt carbon from vehicular exhaust emissions in the atmosphere.

\section{Correlation Analysis}

Table 4 shows the correlation of different air quality parameters. The following results are made according to statistical analysis of data in Table 4.

$\mathrm{O}_{3}$ has a significant negative correlation with $\mathrm{NO}$, $\mathrm{NO}_{2}, \mathrm{NOx}, \mathrm{CH}_{4}, \mathrm{CO}$, and $\mathrm{RH}$ (r-value $>-0.5$ ); and has significant positive correlation with $\mathrm{T}$ and solar radiation ( $\mathrm{r}$-value $>0.5$ ). The level of tropospheric ozone is highly dependent on solar radiation and atmospheric temperature [32], while NO has significant positive correlation with $\mathrm{NO}_{2}, \mathrm{NOx}, \mathrm{CH}_{4}, \mathrm{CO}$, and $\mathrm{RH}$ (r-value $>0.5$ for each); and has negative correlation with $\mathrm{O}_{3}, \mathrm{~T}$, and solar radiation ( $\mathrm{r}$-value $>-0.5$ for each). NO concentration is almost negligible from 07:00-15:00 in the summers due to its conversion into $\mathrm{NO}_{2}$ by reacting with abundant $\mathrm{O}_{3}$ produced by different sources such as $\mathrm{CO}, \mathrm{NO}_{2}, \mathrm{VOCs}$, and NMHCs in the presence of sunlight.

Table 3. Mean values of different pollutants and meteorological parameters (07:00-17:00).

\begin{tabular}{|c|c|c|c|c|c|c|c|c|c|c|c|c|c|}
\hline Variable & $\mathrm{NO}$ & $\mathrm{NO}_{2}$ & $\mathrm{NOx}$ & $\mathrm{CH}_{4}$ & $\mathrm{NMHC}$ & $\mathrm{CO}$ & $\mathrm{SO}_{2}$ & $\mathrm{O}_{3}$ & $\mathrm{PM}_{2.5}$ & $\begin{array}{c}\text { Wind } \\
\text { Speed }\end{array}$ & $\mathrm{T}$ & $\mathrm{RH}$ & $\begin{array}{c}\text { Solar } \\
\text { radiation }\end{array}$ \\
\hline Unit & $\mu \mathrm{g} \mathrm{m}^{-3}$ & $\mu \mathrm{g} \mathrm{m}^{-3}$ & $\mathrm{Ppb}$ & $\mathrm{ppb}$ & $\mathrm{ppb}$ & $\mathrm{mg} \mathrm{m}^{-3}$ & $\mu \mathrm{g} \mathrm{m}^{-3}$ & $\mu \mathrm{g} \mathrm{m}^{-3}$ & $\mu \mathrm{g} \mathrm{m}^{-3}$ & $\mathrm{~m} / \mathrm{s}$ & ${ }^{\circ} \mathrm{C}$ & $\%$ & $\mathrm{~W} \mathrm{\textrm {m } ^ { - 2 }}$ \\
\hline $\begin{array}{c}\text { Mean } \\
\text { Value }\end{array}$ & 1.93 & 28.52 & 16.14 & 2210.61 & 735.85 & 0.68 & 42.64 & 122.50 & 155.07 & 1.72 & 37.68 & 30.66 & 539.35 \\
\hline
\end{tabular}


Table 4. Correlation analysis of ambient air variables of semi-arid region, Lahore.

\begin{tabular}{|c|c|c|c|c|c|c|c|c|c|c|c|c|c|c|}
\hline & & NO & $\mathrm{NO}_{2}$ & NOx & $\mathrm{CH}_{4}$ & NHMC & $\mathrm{CO}$ & $\mathrm{SO}_{2}$ & $\mathrm{O}_{3}$ & $\mathrm{PM}_{2.5}$ & WS & $\mathrm{T}$ & RH & $\begin{array}{c}\text { Solar } \\
\text { radiation }\end{array}$ \\
\hline NO & $\begin{array}{c}\text { Pearson } \\
\text { Correlation }\end{array}$ & 1 & $.946^{* *}$ & $.741^{* *}$ & $.953^{* *}$ & .416 & $.917^{* *}$ & .556 & $-.825^{* *}$ & .163 & .058 & $-.725^{*}$ & $.616^{*}$ & $-.614^{*}$ \\
\hline $\mathrm{NO}_{2}$ & \begin{tabular}{c|} 
Pearson \\
Correlation
\end{tabular} & $.946^{* *}$ & 1 & $.871^{* *}$ & $.978^{* *}$ & .254 & $.912^{* *}$ & .571 & $-.675^{*}$ & .200 & -.084 & $-.634^{*}$ & .496 & $-.660^{*}$ \\
\hline NOx & $\begin{array}{c}\text { Pearson } \\
\text { Correlation }\end{array}$ & $.741^{* *}$ & $.871^{* *}$ & 1 & $.797^{* *}$ & .039 & $.734^{*}$ & .363 & -.520 & .072 & -.138 & -.401 & .249 & $-.635^{*}$ \\
\hline $\mathrm{CH}_{4}$ & $\begin{array}{c}\text { Pearson } \\
\text { Correlation } \\
\end{array}$ & $.953^{* *}$ & $.978^{* *}$ & $.797^{* *}$ & 1 & .214 & $.892^{* *}$ & .576 & $-.714^{*}$ & .094 & -.003 & $-.710^{*}$ & .571 & $-.717^{*}$ \\
\hline NHMC & $\begin{array}{c}\text { Pearson } \\
\text { Correlation }\end{array}$ & .416 & .254 & .039 & .214 & 1 & .336 & .185 & -.238 & .497 & -.157 & -.135 & .184 & .245 \\
\hline $\mathrm{CO}$ & $\begin{array}{c}\text { Pearson } \\
\text { Correlation } \\
\end{array}$ & $.917^{* *}$ & $.912^{* *}$ & $.734^{*}$ & $.892^{* *}$ & .336 & 1 & $.809^{* *}$ & $-.758^{* *}$ & .443 & .224 & $-.805^{* *}$ & $.737^{* *}$ & -.466 \\
\hline $\mathrm{SO}_{2}$ & $\begin{array}{c}\text { Pearson } \\
\text { Correlation }\end{array}$ & .556 & .571 & .363 & .576 & .185 & $.809^{* *}$ & 1 & -.516 & $.654^{*}$ & .519 & $-.820^{* *}$ & $.841^{* *}$ & -.160 \\
\hline $\mathrm{O}_{3}$ & \begin{tabular}{|c|} 
Pearson \\
Correlation \\
\end{tabular} & $-.825^{* *}$ & $-.675^{*}$ & -.520 & $-.714^{*}$ & -.238 & $-.758^{* *}$ & -.516 & 1 & -.004 & -.491 & $.824^{* *}$ & $-.763^{* *}$ & .525 \\
\hline $\mathrm{PM}_{2.5}$ & $\begin{array}{c}\text { Pearson } \\
\text { Correlation }\end{array}$ & .163 & .200 & .072 & .094 & .497 & .443 & $.654^{*}$ & -.004 & 1 & .045 & -.189 & .282 & .487 \\
\hline WS & $\begin{array}{c}\text { Pearson } \\
\text { Correlation }\end{array}$ & .058 & -.084 & -.138 & -.003 & -.157 & .224 & .519 & -.491 & .045 & 1 & $-.678^{*}$ & $.769^{* *}$ & -.088 \\
\hline $\mathrm{T}$ & $\begin{array}{c}\text { Pearson } \\
\text { Correlation }\end{array}$ & $-.725^{*}$ & $-.634^{*}$ & -.401 & $-.710^{*}$ & -.135 & $-.805^{* *}$ & $-.820^{* *}$ & $.824^{* *}$ & -.189 & $-.678^{*}$ & 1 & $-.978^{* *}$ & .523 \\
\hline $\mathrm{RH}$ & $\begin{array}{c}\text { Pearson } \\
\text { Correlation } \\
\end{array}$ & $.616^{*}$ & .496 & .249 & .571 & .184 & $.737^{* *}$ & $.841^{* *}$ & $-.763^{* *}$ & .282 & $.769^{* *}$ & $-.978^{* *}$ & 1 & -.364 \\
\hline Radiation & $\begin{array}{c}\text { Pearson } \\
\text { Correlation }\end{array}$ & $-.614^{*}$ & $-.660^{*}$ & $-.635^{*}$ & $-.717^{*}$ & .245 & -.466 & -.160 & .525 & .487 & -.088 & .523 & -.364 & 1 \\
\hline
\end{tabular}

**Correlation is significant at the 0.01 level (2-tailed).

* Correlation is significant at the 0.05 level (2-tailed)

$\mathrm{NO}_{2}$ has significant positive correlation with $\mathrm{NO}$, $\mathrm{NOx}, \mathrm{CH}_{4}, \mathrm{CO}$, and $\mathrm{SO}_{2}$ (r-value> 0.5 for each), and has significant negative correlation with $\mathrm{O}_{3}$, $\mathrm{T}$, and solar radiation (r-value $>-0.5$ ). In daytime almost all the $\mathrm{NO}$ has been converted to $\mathrm{NO}_{2}$ by reacting with $\mathrm{O}_{3}$ in the presence of sunlight. The dominant sources of nitrogen oxides as far as vehicles are concerned are diesel and four-stroke engines [33].

NOx has a significant positive correlation with $\mathrm{NO}$, $\mathrm{NO}_{2}, \mathrm{CH}_{4}, \mathrm{CO}$, and $\mathrm{SO}_{2}$ (r-value $>0.5$ for each), and has a significant negative correlation with $\mathrm{O}_{3}$ and solar radiation (r-value $>-0.5$ ).

$\mathrm{CH}_{4}$ has significant correlation with $\mathrm{NO}, \mathrm{NO}_{2}, \mathrm{NOx}$, $\mathrm{SO}_{2}$, and $\mathrm{RH}$ (r-value> 0.5 for each), and significant negative correlation with $\mathrm{O}_{3}, \mathrm{~T}$, and solar radiation (r-value $>-0.5$ ).

NMHC has no significant correlation with any of the parameters.

$\mathrm{CO}$ has a significant positive correlation with $\mathrm{NO}, \mathrm{NO}_{2}$, $\mathrm{NOx}, \mathrm{CH}_{4}, \mathrm{SO}_{2}$, and $\mathrm{RH}$,(r-value $>0.5$ for each), and has significant negative relation with $\mathrm{O}_{3}$ and $\mathrm{T}$ (r-value $>-0.5$ ). The correlation studies among $\mathrm{NO}, \mathrm{NO}_{2}, \mathrm{NOx}, \mathrm{CH}_{4}, \mathrm{CO}$, and $\mathrm{SO}_{2}$ suggest that the dominant sources of air pollution are direct or primary in nature. The major sources of
$\mathrm{CO}$ are $\mathrm{CNG}$, LPG, and petrol engines. Diesel engines generate a relatively very low amount of $\mathrm{CO}$. Ambient $\mathrm{CO}$ emissions always remain within the permissible limit of $5 \mathrm{mg} \mathrm{m}^{-3}=5000 \mu \mathrm{g} \mathrm{m}^{-3}$. Therefore, $\mathrm{CO}$ emissions may not be considered low in terms of $\mu \mathrm{g} \mathrm{m}^{-3}$ units. The significant positive correlation between $\mathrm{CO}$ and $\mathrm{NO}$ $(\mathrm{r}=0.72 ; \mathrm{p}$-value $<0.01)$ shows a common source for both. $\mathrm{CNG}$ engines are a main common source for the emission of $\mathrm{CO}$ and $\mathrm{NO}$ [33]. Pakistan has the highest number of vehicles using $\mathrm{CNG}$ fuel [33]. $\mathrm{CO}$ produces $\mathrm{O}_{3}$ through a number of chemical reactions with hydroxyl radicals, and $\mathrm{NO}$ in the polluted environment in the presence of sunlight. The dominant sources of $\mathrm{CO}$ emissions are twoand four-stroke petrol, CNG, and LPG vehicles. Diesel engines produce only a minute amount of $\mathrm{CO}$ emissions [33].

The major source of $\mathrm{SO}_{2}$ emissions are diesel engines and two-stroke LPG vehicles [33]. $\mathrm{SO}_{2}$ has a significant positive correlation with $\mathrm{NO}, \mathrm{NO}_{2}, \mathrm{CH}_{4}, \mathrm{CO}, \mathrm{PM}_{2.5}$, WS, and RH (r-value $>0.5$ for each), and has significant negative correlation with $\mathrm{O}_{3}$ and $\mathrm{T}$. The correlation of $\mathrm{SO}_{2}$ with WS suggests that point sources can be a dominant source for $\mathrm{SO}_{2}$ emissions. The common source for $\mathrm{CO}$ and $\mathrm{SO}_{2}$ are $\mathrm{LPG}$ engines. 
$\mathrm{PM}_{2.5}$ has significant positive correlation only with $\mathrm{SO}_{2}$ (r-value $>0.5$ ). The correlation of $\mathrm{PM}_{2.5}$ with $\mathrm{SO}_{2}$ suggests that most of these pollutants originates with fresh emissions from mobile and point sources. Some amount of $\mathrm{PM}_{2.5}$ may be produced by chemical conversion of $\mathrm{SO}_{2}$ into particles. A negative correlation of $\mathrm{PM}_{2.5}$ with $\mathrm{T}$ has already been reported [34]. Some researchers have reported the conversion of semi-volatile components from particle phase to gas phase at high temperatures [35-38].

Yasar has reported high smoke opacity for most diesel engines, which are a dominant source for $\mathrm{PM}_{2.5}$ [33]. Diesel engines are a dominant source for $\mathrm{SO}_{2}$ and $\mathrm{PM}_{2.5}$ emissions, which explains the high correlation between $\mathrm{PM}_{2.5}$ and $\mathrm{SO}_{2}$.

$\mathrm{RH}$ has significant positive correlation with $\mathrm{NO}, \mathrm{CO}$, $\mathrm{SO}_{2}$, and WS (r-value $>0.5$ ), and significant negative correlation with $\mathrm{O}_{3}$ and $\mathrm{T}$ (r-value $>-0.5$ ). In fact, $\mathrm{RH}$ has significant negative correlation with $\mathrm{T}$ and has very little correlation with other pollutants. The pollutants may have very minute correlations with WS and RH. In other words, it is difficult to explain the correlation of pollutants with WS and RH in the presence of many other factors as well.

In the winter, the excess amount of ammonia at low temperatures and high relative humidity upturns PM by producing nitrate particles $[39,40]$. Temperature has a significant negative correlation with $\mathrm{NO}, \mathrm{NO}_{2}, \mathrm{CH}_{4}, \mathrm{SO}_{2}$, WS, and RH (r-value $>-0.5$ ), and has significant positive correlation with solar radiation and $\mathrm{O}_{3}(\mathrm{r}$-value $>0.5)$ This

Table 5. Ratio analysis based on average emissions and/or ambient data.

\begin{tabular}{|c|c|c|c|}
\hline \multicolumn{2}{|c|}{ Region } & $\mathrm{CO} / \mathrm{NOx}$ & $\mathrm{SO}_{2} / \mathrm{NOx}$ \\
\hline \multirow{3}{*}{ Eastern US } & Ambient & 4.3 & 0.94 \\
\hline & Mobiles & 8.4 & 0.05 \\
\hline & Point Sources & 0.95 & 1.8 \\
\hline \multirow{3}{*}{$\begin{array}{c}\text { Pennsylvania } \\
\text { Area }\end{array}$} & Ambient & 2.6 & 1.7 \\
\hline & Mobiles & 7.8 & 0.05 \\
\hline & Point Sources & 0.8 & 2.3 \\
\hline \multirow{3}{*}{ Western US } & Ambient & 7.3 & 0.19 \\
\hline & Mobiles & 10.5 & 0.05 \\
\hline & Point Sources & 0.18 & 0.44 \\
\hline \multirow{3}{*}{$\begin{array}{c}\text { Denver } \\
\text { Metropolitan } \\
\text { area }\end{array}$} & Ambient & 7.3 & 0.19 \\
\hline & Mobiles & 10.5 & 0.05 \\
\hline & Point Sources & 0.18 & 0.44 \\
\hline Raleigh, NC & Ambient & 16.3 & 0.73 \\
\hline $\begin{array}{l}\text { New Delhi, } \\
\text { India }\end{array}$ & Ambient & 50 & 0.58 \\
\hline \multirow{3}{*}{$\begin{array}{l}\text { Lahore } \\
\text { (Current } \\
\text { Study) }\end{array}$} & Ambient & 16 & 0.52 \\
\hline & Mobiles & 9.71831 & 0.070423 \\
\hline & Point Sources & 0.789474 & 0.131579 \\
\hline
\end{tabular}

explains the production of ozone in the presence of solar radiation at the cost of the precursors of $\mathrm{O}_{3}$.

\section{Ratio Analysis}

High ratios of $\mathrm{CO} / \mathrm{NO}$ and low ratios of $\mathrm{SO}_{2} / \mathrm{NO}$ indicate that mobile sources are the major source of $\mathrm{NO}$, and point sources are the major source for $\mathrm{SO}_{2}$ emissions. The production of NOx is associated with high temperatures during fossil fuel burning. Therefore, NOx is usually produced at high temperatures in four-stroke petrol and diesel engines. However, $\mathrm{SO}_{2}$ is dominantly produced due to high sulfur content in fuel. High sulfur content $(0.25-1 \%)$ is present in diesel available in Pakistan. Therefore, diesel engines are the major anthropogenic source of $\mathrm{SO}_{2}$ emissions in Lahore [33]. As $\mathrm{NOx}$ is abundantly produced by both 4-stroke petrol engines as well as diesel engines at high temperature, the concentration of NOx usually remains high in Lahore city.

An emission inventory has been provided by [41, 42] for $\mathrm{CO}, \mathrm{SO}_{2}$, and $\mathrm{NOx}$. The data of ratio of $\mathrm{CO} / \mathrm{NO}$ and $\mathrm{CO} / \mathrm{SO}_{2}$ is given in Table 5 , which also provides the ratio analysis of $\mathrm{CO}$ by $\mathrm{NOx}$ and $\mathrm{SO}_{2}$ by $\mathrm{NOx}$ provided by different studies, such as one in Denver, CO, US [43]; Boulder, CO, US [44]; Raleigh, NC, US [45]; and New Delhi, India [46]. The above studies show a similar trend of ratios of $\mathrm{CO} / \mathrm{NO}$ and $\mathrm{SO}_{2} / \mathrm{NO}$ as do in the current study.

\section{Analysis of Ozone Formation}

Ozone is a secondary pollutant. The primary sources for ozone are $\mathrm{CO}, \mathrm{VOCs}, \mathrm{CH}_{4}, \mathrm{NO}_{2}$, and solar radiation. A large amount of $\mathrm{O}_{3}$ has also been produced around highvoltage electric lines. Some countries also claim a high amount of $\mathrm{O}_{3}$ due to trans-boundary movements. It has been observed that during summers, almost all the NO has been converted to $\mathrm{NO}_{2}$ by reacting with $\mathrm{O}_{3}$, being produced by different chemical reactions of $\mathrm{CO}, \mathrm{CH}_{4}$, VOCs, and $\mathrm{NO}_{2}$ in the presence of sunlight. Therefore, $\mathrm{NO}$ concentrations remain almost nil in the presence of high solar radiation during the day in summers. A possible dynamic equilibrium between $\mathrm{NO}$ and $\mathrm{NO}_{2}$ is given in "Eq. 2" [47]:

$$
\mathrm{NO}+\mathrm{O}_{3} \leftrightarrow \mathrm{NO}_{2}+\mathrm{O}_{2}
$$

$\mathrm{NO}_{2}$ reacts with oxygen in the presence of sunlight to produce $\mathrm{O}_{3}$ and NO. As the NO concentration is almost nil in day-time in summers, it may be assumed that $\mathrm{O}_{3}$ has been produced in abundant amounts by different primary sources to keep the reaction forward according to the Le Chatlier principle, i.e., almost all the NO has been converted to $\mathrm{NO}_{2}$ due to an abundant amount of $\mathrm{O}_{3}$ being produced by a number of primary sources in the presence of sunlight. Therefore, it can be assumed that $\mathrm{O}_{3}$ concentration measured at day-time in summers (high solar radiations) is the $\mathrm{O}_{3}$ that has been produced by sources other than $\mathrm{NO}_{2}$ or $\mathrm{NOx}$ (as the amount of $\mathrm{O}_{3}$ 
Table 6. Comparison of dependents through paired sample T-test.

\begin{tabular}{|c|c|c|c|}
\hline \multicolumn{2}{|c|}{} & $\mathrm{t}$ & $\mathrm{p}$ \\
\hline Pair 1 & $\mathrm{NO}-\mathrm{O}_{3}$ & -4.872 & .005 \\
\hline Pair 2 & $\mathrm{NO}_{2}-\mathrm{O}_{3}$ & -3.923 & .011 \\
\hline Pair 3 & $\mathrm{NOx}_{-} \mathrm{O}_{3}$ & -4.354 & .007 \\
\hline Pair 4 & $\mathrm{CH}_{4}-\mathrm{O}_{3}$ & 16.787 & .000 \\
\hline Pair 5 & $\mathrm{PM}_{2.5}-\mathrm{O}_{3}$ & 1.811 & .130 \\
\hline Pair 6 & $\mathrm{WS}_{-} \mathrm{O}_{3}$ & -4.977 & .004 \\
\hline Pair 7 & $\mathrm{T}-\mathrm{O}_{3}$ & -3.713 & .014 \\
\hline Pair 8 & $\mathrm{RH}-\mathrm{O}_{3}$ & -3.668 & .014 \\
\hline Pair 9 & Solar radiation $-\mathrm{O}_{3}$ & 15.505 & .000 \\
\hline
\end{tabular}

produced by $\mathrm{NO}_{2}$ has been consumed by NO). Or it may be assumed that whenever the value of NO is negligible, the amount of $\mathrm{O}_{3}$ produced would be that amount of $\mathrm{O}_{3}$ that is produced by sources other than $\mathrm{NO}_{2}$ or $\mathrm{NOx}$.

Another assumption is that sources like VOCs, CO, and $\mathrm{CH}_{4}$ convert $\mathrm{NO}$ to $\mathrm{NO}_{2}$ and higher oxides of nitrogen. The $\mathrm{NO}_{2}$ is further photo-lysed to produce $\mathrm{O}_{3}$. In daytime the value of $\mathrm{NO}$ is negligible due to its conversion to $\mathrm{NO}_{2}$. The value of $\mathrm{NO}_{2}$ or $\mathrm{NOx}$ has been found to be as high as the $\mathrm{O}_{3}$ value. Therefore, a significant positive correlation is observed between $\mathrm{NO}_{2}$ and $\mathrm{O}_{3}$ or between $\mathrm{NOx}$ and $\mathrm{O}_{3}$ in daytime.

To assess the extent of dependence of Ozone on other variables, paired sample t test has been applied on data. The results of paired sample $t$ test are given in Table 6 .

The $t$ value of all the precursors of ozone like NOx, $\mathrm{CH}_{4}$, temperature, and solar radiation is non-zero. The $\mathrm{p}$ value of $\mathrm{NO}, \mathrm{NO}_{2}, \mathrm{NOx}, \mathrm{T}$, and solar radiation are less than or very close to 0.01 ( $99 \%$ confidence level), indicating their significant effect on ozone. For $\mathrm{PM}_{2.5}$ p-value is 0.13 , indicating no significant dependence of Ozone on $\mathrm{PM}_{2.5}$. Although $\mathrm{p}$ values for wind speed and RH are close to 0.01 , practically $\mathrm{RH}$ has no significant relation for ozone, and the dependence of ozone on wind speed depends on wind direction.

\section{Diurnal and Monthly Mean Pattern of Air Quality Parameters}

It has been observed that all the primary pollutants like $\mathrm{CH}_{4}, \mathrm{NMHC}, \mathrm{CO}, \mathrm{NO}, \mathrm{NO}_{2}, \mathrm{NOx}, \mathrm{SO}_{2}$, and $\mathrm{PM}_{2.5}$ have positive correlations with each other and negative correlations with $\mathrm{O}_{3}$. The peak value of $\mathrm{O}_{3}$ has been observed in the daytime due to the presence of high solar radiation, especially in summers. In the absence or reduction of light at night, almost nil or minimum values of $\mathrm{O}_{3}$ have been observed. The diurnal variations remain the same in every season and all months of the calendar. The value of $\mathrm{O}_{3}$ has been observed as very high during the summer noon due to high solar radiation. Maximum pollution of primary pollutants has been observed from

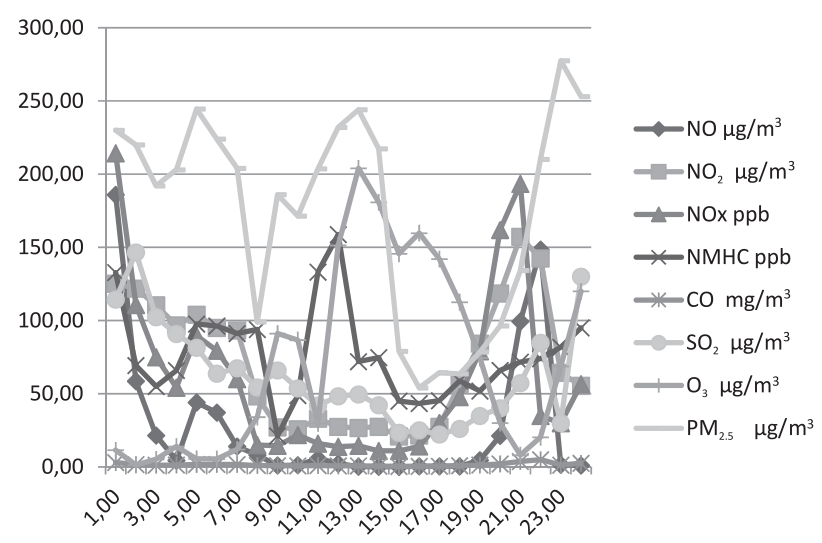

Fig. 2. Diurnal trends of air quality pollutants in the semi-arid region of Lahore.

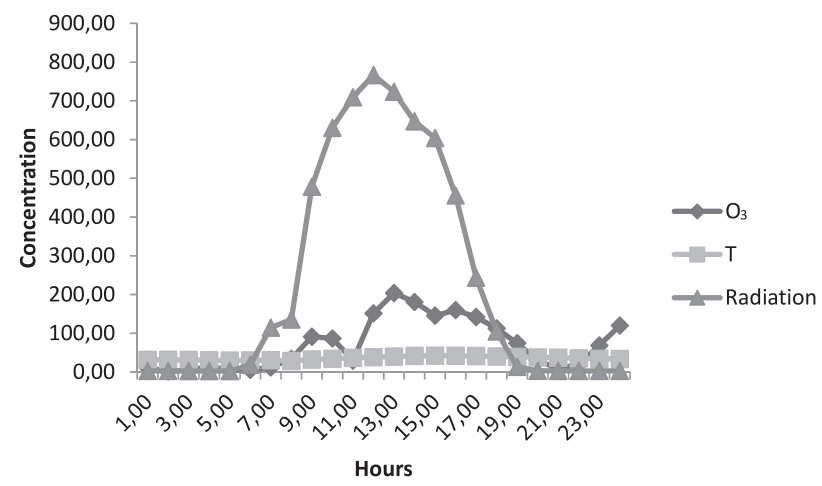

Fig. 3. Diurnal trends of ozone, temperature (T), and solar radiation.

November to February due to low solar radiation and low photochemical reactions to produce $\mathrm{O}_{3}$. Fig. 2 shows the diurnal variation of $\mathrm{O}_{3}$ and other pollutants, while Fig. 3 shows the significant correlation of $\mathrm{O}_{3}$ with temperature and solar radiation. In Fig. $3, \mathrm{CH}_{4}$ levels are divided by 100 , NMHC are divided by 10 , and CO levels are multiplied by 10 to better elaborate upon their monthly patterns.

\section{Seasonal Pattern of Ozone and other Air Quality Parameters}

There are five different seasons in Lahore. The two main seasons are winter and summer with extreme climatic conditions. As already discussed, $\mathrm{O}_{3}$ has a significant correlation with temperature $(r=0.7$; Table 3$)$. The value of $\mathrm{O}_{3}$ remains high during summers due to high solar radiation. The concentration of precursors of $\mathrm{O}_{3}$ remains high during winter mainly due to low solar radians.

The main features of winter in Lahore are:

- Low wind speed,

- Low solar radiation/temperature

- Less precipitation

This favors accumulation and inversion of air pollutants. Therefore, the highest air pollution has been 


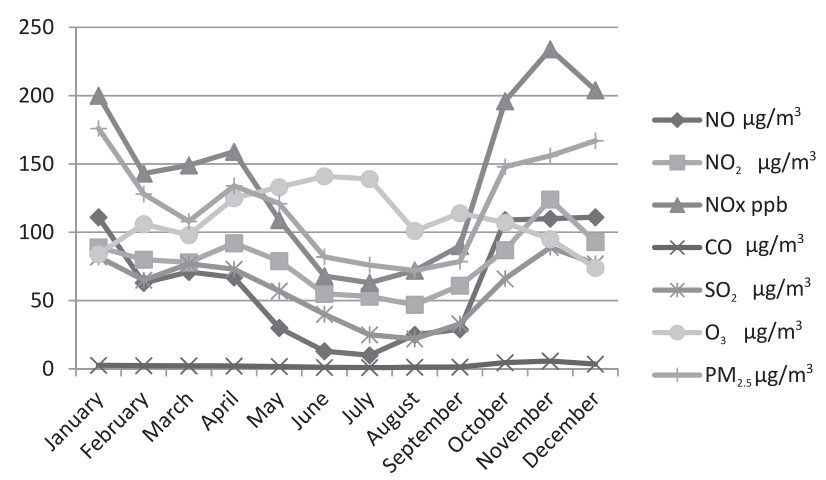

Fig. 4. Seasonal/Monthly patterns of air quality pollutants in the semi-arid region of Lahore.

found from November to February in Lahore as a semiarid region. But concentrations of secondary $\mathrm{O}_{3}$ pollutants remain low in winter due to low solar radiation.

Summer is composed of:

- Relatively high wind speed

- High solar radiation/temperature

- Monsoon rains during July and August

All these factors results in the dispersion and washout of air pollutants. But $\mathrm{O}_{3}$ concentrations remain high during summers due to high solar radiation. Fig. 4 elaborates upon the monthly pattern of $\mathrm{O}_{3}$ and other pollutants.

\section{Conclusions}

We have characterized the ambient air quality for criteria pollutants for Lahore, Pakistan. The annual average concentrations of $\mathrm{PM}_{2.5}$ and $\mathrm{NO}$ are exceeding the Pak-NEQS. The NEQS for $\mathrm{PM}_{2.5}$ needs to be relaxed for a semi-arid region as $\mathrm{PM}_{2.5}$ levels are exceeding strict NEQS of $35 \mu \mathrm{g} \mathrm{m}-3$, even in rural areas around the city.

24 hours and annual Pak-NEQS have not been established for ozone, although its concentration remains too high during summers. Mobile sources are a major source of such high concentrations of NO. The hourly average concentrations of ozone exceed the Pak-NEQS primarily during summer. Carbon monoxide and sulfur dioxide are found to remain in compliance with the PakNEQS for the entire calendar year.

The monthly pattern of pollutants show that AQI remains high during winter due to relatively low washing effect (low rain), low wind speed, and high inversion. Moreover, the dominant wind direction from the southeast enables the polluting steel industry to contribute to pollution of Lahore in winter. But ozone levels remain low during winter due to low solar radiation. The diurnal trend of pollutants is similar to the monthly pattern, i.e., AQI remains low in the daytime at high $\mathrm{T}$ and solar radiation. The concentration of primary pollutants like $\mathrm{NO}, \mathrm{NO}_{2}$, NOx, $\mathrm{CO}, \mathrm{SO}_{2}, \mathrm{CH}_{4}, \mathrm{NMHC}$, and $\mathrm{PM}_{2.5}$ remains low in the daytime due to their use as a precursor of $\mathrm{O}_{3}$, dispersion effect, and many other factors. The ozone level remains high in the daytime (like in summers) due to high solar radiation and the presence of high concentrations of its precursors.

Ozone has positive correlation with $\mathrm{T}$ and solar radiation, and negative correlation with most pollutants like $\mathrm{NO}, \mathrm{NO}_{2}, \mathrm{NOx}, \mathrm{CO}$, and $\mathrm{CH}_{4}$. Wind speed, $\mathrm{T}$, and solar radiation have negative correlations with primary pollutants. A wide range of fluctuation in NO concentration has been observed in the presence and absence of solar radiation. Ozone in the presence of solar radiation has a reduction effect for most pollutants other than $\mathrm{PM}_{2.5}$ and NMHC.

Correlation studies suggest that the dominant sources of the primary pollutants are fossil fuels, either from mobile sources or point sources. Four-stroke petrol engines are a common source for $\mathrm{CO}, \mathrm{NO}, \mathrm{NO}_{2}$, and $\mathrm{NOx}$, which are precursors of $\mathrm{O}_{3}$. Diesel engines are a major common source for NOx, $\mathrm{SO}_{2}$, and $\mathrm{PM}_{2.5}$. There is a need to reduce sulfur contents in diesel being used in Pakistan. $\mathrm{SO}_{2}$ emissions mostly remain in compliance with NEQS in Lahore, as most of the vehicles use petrol as fuel. As NOx are abundantly produced by diesel and four-stroke petrol engines, the concentration of NOx mostly remains high in Lahore. Ratio analysis showed that mobile sources are the major sources for $\mathrm{NO}$ and point sources are the major source for $\mathrm{SO}_{2}$ emissions in the city hall area of Lahore.

Ozone is a dreadful pollutant for road traffic for arid and semi-arid areas in summer. There is a need to collect more data of its other primary precursors like VOCs as well.

The population of Lahore has been increasing at a very fast pace. There is a need to stop migration through the provision of health, education, employment, industrial, and fast transport facilities in other cities and remote areas as well.

There is also a need to provide better and more accessible public transport for all the housing societies of Lahore, to promote the use of public transport, and to lessen the use of private vehicles - especially cars.

\section{Acknowledgments}

We are thankful to Pak Green Laboratories for provision of instruments for air quality monitoring in Lahore, especially by Mr. Iftekhar and Abdul Hafeez Nasir. We are thankful to Mr. Nadeem, Riaz Ahmad, Ajmal Nadeem, Baber Zaheer, and Ms. Amina Basharat from Punjab EPA for their expert opinions and data provision. Mr. Abdul Khaliq Alvi from Garrison University and Amjid Ali Zafar from the Labor and Human Resource Department are acknowledged for data analysis. Mr. Imran Haider is acknowledged for financial help. Special thanks to Mr. Toshiharu Ochi, JICA expert, for his valuable guidance regarding air pollution monitoring.

\section{References}

1. Bureau of Statistics. Punjab Development Statistics 2012, Government of Punjab, Lahore. 
2. STONE E., SCHAUER J., QURAISHI T.A., MAHMOOD A., Chemical characterization and source apportionment of fine and coarse particulate matter in Lahore, Pakistan. Atmospheric Environment, 44 (8), 1062, 2010.

3. SHAHID M., AHMAD N., HUSSAIN K., NASEEM S. Compound phase analysis of solid aerosols collected from different locations of Faisalabad and Lahore (Pakistan) using Matrix-Flushing Method. Peak Journal of Physical and Environmental Science Research, 1, 54, 2013.

4. AZIZ A., BAJWA I., AHMAD I., MAYO S., RAHMAN A. Urban Air Quality and Unrelenting Peril of Vehicular Emission (Policy And Priorities of City District Government Lahore). Pakistan Journal of Science, 65 (2), 2013.

5. International Monetary Fund Pakistan: Poverty reduction strategy paper, International Monetary Fund, Washington, D.C.2010.

6. ASSISTANCE C., SHYAMSUNDAR P., HAMILTON K., SEGNESTAM L., SARRAF M., FANKHAUSER S. The World Bank Environment Department. World, 2001.

7. PUROHIT P., MUNIR T., RAFAJ P. Scenario analysis of strategies to control air pollution in Pakistan. Journal of Integrative Environmental Sciences, 10 (2), 77, 2013.

8. WANG H., COLVILE R.N., PAIN C., ARISTODEMOU E., APSIMON H.M. Understanding peak pedestrian exposures due to traffic emissions within the urban environment. Transportation research part D: transport and environment, $16(5), 392,2011$.

9. BILENKO N., VAN ROSSEM L., BRUNEKREEF B., BEELEN R., EEFTENS M., HOEK G., HOUTHUIJS D., DE JONGSTE J.C., VAN KEMPEN E., KOPPELMAN G.H. Traffic-related air pollution and noise and children's blood pressure: results from the PIAMA birth cohort study. European journal of preventive cardiology, 22 (1), 4, 2015.

10. KUNDU S., QURAISHI T., YU G., SUAREZ C., KEUTSCH F., STONE E. Evidence and quantitation of aromatic organosulfates in ambient aerosols in Lahore, Pakistan. Atmospheric chemistry and physics, 13 (9), 4865, 2013.

11. RASHEED A., ANEJA V.P., AIYYER A., RAFIQUE U. Measurement and analysis of fine particulate matter $\left(\mathrm{PM}_{2.5}\right)$ in urban areas of Pakistan. Aerosol Air Qual. Res, 15, 426, 2015.

12. TARIQ S., ALI M., MAHMOOD K., BATOOL S.A., RANA A.D. A study of tropospheric $\mathrm{NO}_{2}$ variability over Pakistan using OMI data. Atmospheric Pollution Research, 5 (4), 709, 2014.

13. SINGH R.P., KASKAOUTIS D.G. Crop residue burning: a threat to South Asian air quality. Eos, Transactions American Geophysical Union, 95 (37), 333, 2014.

14. MCMURRY P., SHEPHERD M., VICKERY J. NARSTO Particulate matter science for policy makers: a NARSTO assessment, Cambridge University Press, Cambridge. 2004.

15. ZHANG Y., QURAISHI T., SCHAUER J.J. Daily Variations in Sources of Carbonaceous Aerosol in Lahore, Pakistan during a High Pollution Spring Episode. Aerosol Air Qual. in Res. Citeseer. 2008.

16. JACOB D.J., WINNER D.A. Effect of climate change on air quality. Atmospheric Environment, 43 (1), 51, 2009.

17. ANEJA V.P., SCHLESINGER W.H., ERISMAN J.W. Effects of agriculture upon the air quality and climate: Research, policy, and regulations. Environmental Science \& Technology, 43 (12), 4234, 2009.

18. VIIDANOJA J., SILLANPÄÄ M., LAAKIA J., KERMINEN V.-M., HILLAMO R., AARNIO P., KOSKENTALO T., Organic and black carbon in $\mathrm{PM}^{2.5}$ and $\mathrm{PM}_{10}: 1$ year of data from an urban site in Helsinki, Finland. Atmospheric Environment, 36 (19), 3183, 2002.
19. HUSAIN L., DUTKIEWICZ V.A., KHAN A., GHAURI B.M. Characterization of carbonaceous aerosols in urban air. Atmospheric Environment, 41 (32), 6872, 2007.

20. DAS S.K., CHATTERJEE A., GHOSH S.K., RAHA S. Fog-Induced Changes in Optical and Physical Properties of Transported Aerosols over Sundarban, India. Aerosol and Air Quality Research, 15 (4), 1201, 2015.

21. NIAZ Y., ZHOU J., IQBAL M., NASIR A., DONG V. Ambient air quality evaluation: a comparative study in China and Pakistan. Polish Journal of Environmental Studies, 24 (4), 2015

22. BASARIĆ V., ĐORIĆ V., BOGDANOVIĆ V., MITROVIĆ J., JOVIĆ J. Effects of Traffic on $\mathrm{NO}_{2}$ and $\mathrm{PM}_{10}$ Emissions in Novi Sad. Polish Journal of Environmental Stidies, 23 (5), 2014.

23. GUTTIKUNDA S.K. Emissions from the Brick Manufacturing Industry, in Dhaka Megacity. Springer. 319, 2014.

24. KATULSKI R., STEFANSKI J., SADOWSKI J., AMBROYIAK S., NAMIESNIK S., WARDENCKI W. Mobile monitoring system for control of atmospheric air quality. Polish Journal of Environmental Studies, 20 (3), 677, 2011.

25. ANWARZ K., EJAZ S., ASHRAF M.,AHMAD N., JAVEED A., Monitoring trace elements generated by automobiles: air pollutants with possible health impacts. Environmental Science and Pollution Research, 20 (7), 4574, 2013.

26. ZHANG C., HE X., LI Z., ZHANG S., LI H., JIN M., LI Y. Perfluorinated Compounds (PFCs) in Ambient Air Particulates PM. 2016.

27. MARTIN P., NISHIDA J., AFZAL J., AKBAR S., DAMANIA R., HANRAHAN D. Pakistan strategic country environmental assessment. South Asia Region, World Bank, $1,2006$.

28. ABRAR A., SUNDAS W., PERVEEN F., HABIB M. Air Quality Monitoring of some Gaseous Pollutants at selected points in Gullberg II, Lahore, Pakistan Int. Res. J. Env. Sci, 3 (6), 38, 2014.

29. Wikipedia. Climate of Islamabad, Retrieved from https:// en.wikipedia.org/wiki/Climate_of_Lahore on May 10, 2015

30. OFFICER A.A.A., GENERAL A.A., REVENUE A.A.G.P., OFFICER D.D.A., GENERAL D.D. Environmental Assessment Report of the Civil Works Component of the Project to Improve Financial Reporting and Auditing (PifraIi).

31. GONG J., HU Y., LIU M., BU R., CHANG Y., LI C., WU W. Characterization of Air Pollution Index and its affecting factors in industrial urban areas in Northeastern China. Pol. J. Environ. Stud, 24, 1579, 2015.

32. SWACKHAMER D.L., Rethinking the Ozone Problem in Urban and Regional Air Pollution: National Research Council. National Academy Press (1991). Pergamon, 1993.

33. YASAR A., HAIDER R., TABINDA A.B., KAUSAR F., KHAN M. A comparison of engine emissions from heavy, medium, and light vehicles for $\mathrm{CNG}$, diesel, and gasoline fuels. Polish Journal of Environmental Studies, 22 (4), 1277, 2013.

34. TIWARI S., CHATE D., SRIVASTAVA M., SAFAI P., SRIVASTAVA A., BISHT D., PADMANABHAMURTY B. Statistical evaluation of $\mathrm{PM}_{10}$ and distribution of $\mathrm{PM}_{1}, \mathrm{PM}_{25}$, and $\mathrm{PM}_{1} 0$ in ambient air due to extreme fireworks episodes (Deepawali festivals) in megacity Delhi. Natural hazards, 61 (2), 521, 2012.

35. DAWSON J., ADAMS P., PANDIS S. Sensitivity of $\mathrm{PM}_{2.5}$ to climate in the Eastern US: a modeling case study. Atmospheric chemistry and physics, 7 (16), 4295, 2007. 
36. SHEEHAN P.E., BOWMAN F.M. Estimated effects of temperature on secondary organic aerosol concentrations. Environmental Science \& Technology, 35 (11), 2129, 2001.

37. AW J., KLEEMAN M.J. Evaluating the first-order effect of intraannual temperature variability on urban air pollution. Journal of Geophysical Research: Atmospheres, 108 (D12), 2003.

38. KANAKIDOU M., MIHALOPOULOS N., KALIVITIS N., TSIGARIDIS K., KOUVARAKIS G., KOULOURI E., GERASOPOULOS E., VREKOUSSIS M., MYRIOKEFALITAKIS S. Natural contributions to particulate matter levels over Europe - the experience from Greece. in International Conference on Science and Technology (CEST). 2007.

39. PITCHFORD M.L., POIROT R.L., SCHICHTEL B.A., MALM W.C. Characterization of the winter midwestern particulate nitrate bulge. Journal of the Air \& Waste Management Association, 59 (9), 1061, 2009.

40. RAJA S., BISWAS K.F., HUSAIN L., HOPKE P.K. Source apportionment of the atmospheric aerosol in Lahore, Pakistan. Water, Air, and Soil Pollution, 208 (1-4), 43, 2010.

41. KLIMONT Z., SMITH S.J., COFALA J. The last decade of global anthropogenic sulfur dioxide: 2000-2011 emissions. Environmental Research Letters, 8 (1), 014003, 2013.

42. DARRAS S., GRANIER C., PIGNOT V., BODICHON R., BOONNE C., LIOUSSE C., PAULIN M. ECCAD: Emission of Atmospheric Compounds \& Compilation of Ancillary Data. in AGU Fall Meeting Abstracts. 2010.

43. PARRISH D.D., TRAINER M., BUHR M.P., WATKINS B.A., FEHSENFELD F.C. Carbon monoxide concentrations and their relation to concentrations of total reactive oxidized nitrogen at two rural U.S. sites, J. Geophys. Res., 96, 9309, 1991.

44. GOLDAN P., TRAINER M., KUSTER W., PARRISH D., CARPENTER J., ROBERTS J., YEE J., FEHSENFELD F., Measurements of hydrocarbons, oxygenated hydrocarbons, carbon monoxide, and nitrogen oxides in an urban basin in Colorado: Implications for emission inventories. Journal of Geophysical Research: Atmospheres, 100 (D11), 22771, 1995.

45. ANEJA V.P., KIM D.-S., CHAMEIDES W.L. Trends and analysis of ambient $\mathrm{NO}, \mathrm{NO} \mathrm{y}, \mathrm{CO}$, and ozone concentrations in Raleigh, North Carolina. Chemosphere, 34 (3), 611, 1997.

46. ANEJA V.P., AGARWALA., ROELLE P.A., PHILLIPS S.B., TONG Q., WATKINS N., YABLONSKY R. Measurements and analysis of criteria pollutants in New Delhi, India. Environment International, 27 (1), 35, 2001.

47. SEINFELD J.H., PANDIS S.N. Atmospheric chemistry and physics: from air pollution to climate change. John Wiley \& Sons. 2016. 